\title{
Malnutrition and Inflammation
}

\author{
Jorge R. Mujico, Fátima Pérez-de-Heredia, \\ Sonia Gómez-Martínez and Ascensión Marcos \\ Institute of Food Science, Technology and Nutrition (ICTAN-CSIC) \\ Spain
}

\section{Introduction}

The relationship between nutrition and immune function is being widely recognized, although its study is relatively recent. The 1968 World Health Organisation monograph about "Interactions between Nutrition and Infection" presented the mechanisms linking infection and poor nutritional status. Following the development of immunology as a science, increasing evidence was obtained as well to show how undernutrition impaired resistance to infections and the immune response. It was initially recognized that deficits in certain micronutrients (like vitamins and minerals) had a direct impact on immune function. But the relationship between immune function and nutrition extends far beyond that, and the term immunonutrition has been coined. We are now aware of many conditions of nutritional imbalance (not all necessarily linked to nutritional deficiencies) that lead to impaired immune response. For instance, it is currently believed that nutrition is a key factor in the onset and development of many types of cancer, or that the dietary component of atherosclerosis risk can directly influence immune cells and the inflammatory response; certain nutrients, like seed and fish oils have been shown to respectively induce the release of pro- and anti-inflammatory mediators. Accordingly, the idea of undernutrition has been replaced by that of malnutrition, meaning that inappropriate nutrition or nutritional imbalance per se, whether it implies a nutrient deficit or not, influences immune function. That is the reason why overnutrition, or an excessive energy intake, is also now considered as malnutrition.

In this chapter we will discuss three paradigmatic cases of malnutrition that have a strong immune and inflammatory impact: anorexia nervosa (AN) and bulimia nervosa (BN), as examples of severe undernutrition; obesity, also referred to as overnutrition; and celiac disease (CD), a pathological reaction of the body to a particular type of nutrients that leads to malnutrition. Although these nutrition-related diseases have different origins (psychological for eating disorders, modifiable lifestyle factors for obesity and autoimmune for $\mathrm{CD}$ ), they all have in common to present an important inflammatory component and to have nutritional treatment as the main therapeutic approach.

\section{Eating disorders}

Anorexia nervosa (AN) and bulimia nervosa (BN) are states of malnutrition of psychiatric origin. Although conventionally $\mathrm{AN}$ has been described among adolescents, the prevalence 
of this syndrome is now increasing in prepubertal girls. Since AN starts at very early stages of life, and often implies a chronic and disabling course, severe consequences on somatic and mental health may be developed in adulthood (Marcos et al., 2003). Besides a reduced growth, diminished reproduction rate and an increased risk of osteoporosis, a prolonged course of the disorder may impact on the development of the anorexic patients' brain function, probably due to hormonal dysfunctions coming from the corticoid and gonadal systems, and to severe changes in neuropeptides, all these alterations promoting hence disturbance of the immune system of these patients (Table 1).

\begin{tabular}{|l|l|l|}
\hline Biomarker & Alteration & Reference \\
\hline Adiponectin & Increased & Leoni et al., 2010 \\
\hline CD4 $^{+}$CD8 $^{+}$ & Decreased & Marcos et al., 1993 \\
\hline C3 (complement) & Decreased & Flierl et al., 2011 \\
\hline Ghrelin & Increased & Terashi, 2011 \\
\hline IL-1 & Increased & Allende et al., 1998 \\
\hline IL-6 & Increased & Nova \& Marcos, 2006 \\
\hline Lymphocytes & Decreased & Marcos et al., 1993 \\
\hline Resistin & Decreased & Leoni et al., 2010 \\
\hline TNF-a & Increased & Nova \& Marcos, 2006 \\
\hline
\end{tabular}

Table 1. Inflammation-related blood biomarkers altered in eating disorders

Despite the seriously malnourished state of patients with $\mathrm{AN}$ and $\mathrm{BN}$, controversial findings have been published regarding some aspects of the immune system that are otherwise impaired in more typical types of malnutrition, such as protein-energy malnutrition (Nova \& Marcos, 2006). In this respect, it should be noted that recent neurobiological insights into this gut-brain crosstalk have revealed a complex, bidirectional communication system that not only ensures the proper maintenance of gastrointestinal homeostasis and digestion but is likely to have multiple effects on affect, motivation and higher cognitive functions, including intuitive decision making. Moreover, disturbances of this system have been involved in a wide range of disorders, including functional and inflammatory gastrointestinal disorders, obesity and eating disorders (Mayer, 2011).

\subsection{Altered immunity in eating disorders}

Anemia, leukopenia and thrombocytopenia are frequent complications of AN (Cleary et al., 2010) together with relative lymphocytosis (Marcos et al., 1993). Anemia tends to be normocytic and normochromic. Leukopenia manifests as a deficiency of lymphocytes or neutrophils. Thrombocytopenia, if severe, may confer a bleeding risk. However, cellmediated immunity is usually altered in AN and BN as reflected by lymphocyte subset counts and the response to delayed hypersensitivity tests. Regarding the helper/cytotoxic T cell ratio $\left(\mathrm{CD}^{+}: \mathrm{CD}^{+}\right)$, an immunological marker of the nutritional status, the results of our studies on AN and BN patients showed that the duration of the eating disorder and the time when appropriate treatment is achieved are likely contributors to the alteration of this ratio. Immune-competent cell line deficiencies related solely to AN often resolve with nutritional rehabilitation. 
The association between lymphocyte subsets and several psychopathological variables which had proved to be able to affect immune cell count in other conditions was investigated in BN patients. A negative correlation between impulsivity and $\mathrm{T}$ helper cells $\left(\mathrm{CD}^{+}\right)$was found in controls. In the BN group, the patients with higher anxiety had the lower lymphocyte count, and anxiety and hostility were negatively related to CD4 ${ }^{+}$count. In addition, helper/cytotoxic $\mathrm{T}$ cell ratio negatively correlated in this group with impulsivity, hostility, and depression. In the light of these results, the potential influence of psychopathology on lymphocyte subset counts seems to be specific in BN patients, and more relevant than in healthy controls (Vaz-Leal et al., 2010).

Moreover, the complement cascade, a major component of innate immunity, represents a driving force in the pathophysiology of multiple inflammatory disorders. The role of complement in AN remains poorly understood. Serum C3 levels were significantly lower in patients with AN than in controls. There was a strong correlation between index $\mathrm{C} 3$ levels and BMI. Therefore, the $\mathrm{C} 3$ complement factor serum levels may represent a sensitive new biomarker for monitoring the severity of disease in AN (Flierl et al., 2011).

\subsection{Relationship between eating disorders and the neuroendocrine/immune systems}

Immune impairments in AN are less severe than would be expected considering the highly deficient nutritional status of these patients, and also, they seem to be surprisingly free of infectious complications or even common viral infections, at least until the most advanced stages of debilitation (Marcos, 2000). Hypothetically, some of the complex interactions occurring between cytokines and the endocrine system and the central nervous system could provide some compensatory mechanisms to adapt to the limited nutrient supply and possibly result in the perceived lack of infection symptoms. A dysregulated cytokine production and the altered acute-phase response to infection, as well as cortisol and leptin, are considered to be potential factors involved in the adaptation processes occurring in these syndromes (Nova et al., 2002).

Productions of cytokines [interferon (IFN)- $\gamma$, interleukin (IL)-2, tumor necrosis factor (TNF)$a$, IL-6, and IL-1 $\beta$ ] involved in the regulation of the immune response are dysregulated in AN patients. In the context of inflammation, pro-inflammatory cytokines can access the central nervous system and interact with a cytokine network in the brain to influence virtually every aspect of brain function relevant to behaviour, including neurotransmitter metabolism, neuroendocrine function, synaptic plasticity, and neurocircuits that regulate mood, motor activity, motivation, anxiety, and alarm.

TNF-a and IL-6 are two pro-inflammatory cytokines that are involved as mediators of cancer associated cachexia. Similarly, an association has been postulated between elevated plasma levels of pro-inflammatory cytokines in AN and the manifestations of anorexia, cachexia and osteoporosis in these patients. These hypothesis conceive of cytokines as the fundamental regulators of body metabolism in AN and BN. However, it is evident that not all AN patients display the same changes in immune function and cytokine production (Nova \& Marcos, 2006). A variable lymphocyte proliferative response to different mitogens has been reported in anorectic subjects (Polack et al., 1993). Different results for cytokine production by peripheral blood mononuclear cells (PBMCs) have also been reported. For instance, a higher spontaneous production of IL-1 by PBMCs has been reported in AN patients in comparison with a control group (Allende et al., 1998), while no differences were observed under similar conditions in other studies (Bessler et al., 1993; Vaisman et al., 1996). 
Since complex interactions occur between cytokines and the central nervous system, differences in the capacity of AN patients to evoke a compensatory mechanism through either the neuroendocrine system or the autonomic nervous system could explain the variability of the results found (Nova et al., 2002).

In fact, there is a study that shows specific adipocytokines profiles depending on the subtype of AN: restrictive versus binge/purge and hyperactive versus non-hyperactive forms. These biological signatures have been suggested to interfere with the outcome of the disease (Nogueira et al., 2010). The changes in neuropeptides and in the hypothalamic axis that mediate these changes also receive input from neuroendocrine signals sensitive to satiety and food intake and in turn may be poised to provide significant energy conservation. In fact, leptin is a key hormone in the regulation of food intake, energy expenditure, and neuroendocrine, and alters the immune function. Leptin is also related with obesity and its metabolic disorders; starvation-induced depletion of fat stores is accompanied by alterations of circulating adipocytokines that may have potential repercussions in the pathophysiology of AN. Adiponectin enhances insulin sensitivity, controls body weight, prevents atherosclerosis and negatively regulates immune functions. Plasma adiponectin relates inversely to adiposity and reflects the sequelae of accumulation of excess adiposity. Resistin is a protein hormone produced both by adipocytes and immunocompetent cells that affect fuel homeostasis and insulin action. Plasma resistin levels are decreased in AN, while plasma adiponectin levels are increased. Visfatin seems to correlate with visceral fat mass in patients with obesity. Its possible role in patients with AN is unknown (Leoni et al., 2010). Plasma ghrelin levels present opposite changes in obesity and AN, suggesting that ghrelin is a good marker of nutritional status. This molecule, increased in subjects with restrictive AN, is normalized after refeeding (Terashi et al., 2011).

\section{Obesity}

Obesity is characterized by the hypertrophy of the adipose tissue, which has its roots in a positive energy balance. It has been long regarded as a mere state of overnutrition -an esthetical issue rather than a real disease. However, obesity appears often linked to metabolic disturbances, like insulin resistance, type 2 diabetes, non-alcoholic fatty liver disease, or coronary events. The underlying cause of these relationships appears to be an inflammatory response initiating in adipose tissue. Indeed, obesity is a state of low-grade chronic systemic inflammation and is associated as well to an altered immune function (Table 2).

\subsection{Adipose tissue as an immune organ}

There are various histological and functional connections between adipose tissue and the immune system, starting with the fact that immune cells -mainly macrophages and lymphocytes- are normally found in the non-adipose fraction of the tissue (Caspar-Bauguil et al., 2005). In addition, white adipocytes have been suggested to share embryonic origin with immune cells, and characterization of adipose tissue-resident lymphocytes led to the notion that it was an ancestral immune organ (Caspar-Bauguil et al. 2005; Saely et al. 2010). Recently, immature hematopoietic cells have been found in adipose tissue, so that it has been proposed as a site for formation and maturation of immune cell precursors (Poglio et al. 2010). 


\begin{tabular}{|c|c|c|c|}
\hline Biomarker & Source & Alteration & Reference \\
\hline Adiponectin & Blood & $\begin{array}{l}\text { Decreased circulating } \\
\text { values }\end{array}$ & $\begin{array}{l}\text { Arita et al. 1999, as cited in } \\
\text { Tilg \& Moschen } 2006 .\end{array}$ \\
\hline Leptin & Blood & $\begin{array}{l}\text { Increased circulating } \\
\text { values }\end{array}$ & $\begin{array}{l}\text { Bulló et al. 2003, as cited in } \\
\text { Trayhurn \& Wood } 2004\end{array}$ \\
\hline M-CSFR & $\begin{array}{l}\text { Adipose tissue } \\
\text { macrophages }\end{array}$ & $\begin{array}{l}\text { Increased gene expression } \\
\text { (in mice) }\end{array}$ & Weisberg et al. 2003 \\
\hline CD68 & $\begin{array}{l}\text { Adipose tissue } \\
\text { macrophages }\end{array}$ & $\begin{array}{l}\text { Increased gene expression } \\
\text { (in mice) }\end{array}$ & Weisberg et al. 2003 \\
\hline TNF- $a$ & $\begin{array}{l}\text { Adipose tissue } \\
\text { macrophages, } \\
\text { adipocytes }\end{array}$ & $\begin{array}{l}\text { Increased gene expression } \\
\text { (in rodents and humans) }\end{array}$ & $\begin{array}{l}\text { Reviewed in Wellen \& } \\
\text { Hotamisligil } 2005\end{array}$ \\
\hline TNF-Rs & Blood & $\begin{array}{l}\text { Increased circulating } \\
\text { values }\end{array}$ & $\begin{array}{l}\text { Bulló et al. 2003, as cited in } \\
\text { Trayhurn \& Wood } 2004\end{array}$ \\
\hline IL-6 & $\begin{array}{l}\text { Adipose tissue } \\
\text { macrophages, } \\
\text { adipocytes }\end{array}$ & $\begin{array}{l}\text { Increased gene expression } \\
\text { (in mice) }\end{array}$ & $\begin{array}{l}\text { Reviewed in Wellen \& } \\
\text { Hotamisligil } 2005\end{array}$ \\
\hline IL-6 & Blood & $\begin{array}{l}\text { Increased circulating } \\
\text { values }\end{array}$ & $\begin{array}{l}\text { Bulló et al. 2003, as cited in } \\
\text { Trayhurn \& Wood } 2004\end{array}$ \\
\hline IL-8 & $\begin{array}{l}\text { Adipose tissue } \\
\text { macrophages, } \\
\text { adipocytes }\end{array}$ & $\begin{array}{l}\text { Increased gene expression } \\
\text { (in mice) }\end{array}$ & $\begin{array}{l}\text { Reviewed in Wellen \& } \\
\text { Hotamisligil } 2005\end{array}$ \\
\hline MCP-1 & Adipocytes & $\begin{array}{l}\text { Increased gene expression } \\
\text { (in mice) }\end{array}$ & $\begin{array}{l}\text { Reviewed in Wellen \& } \\
\text { Hotamisligil } 2005\end{array}$ \\
\hline CRP & Adipocytes & $\begin{array}{l}\text { Increased gene expression } \\
\text { (in mice) }\end{array}$ & $\begin{array}{l}\text { Reviewed in Wellen \& } \\
\text { Hotamisligil } 2005\end{array}$ \\
\hline CRP & Blood & $\begin{array}{l}\text { Increased circulating } \\
\text { values }\end{array}$ & $\begin{array}{l}\text { Wärnberg et al. } 2006 \\
\text { Bulló et al. 2003, as cited in } \\
\text { Trayhurn \& Wood } 2004\end{array}$ \\
\hline $\mathrm{C} 3, \mathrm{C} 4$ & Blood & $\begin{array}{l}\text { Increased circulating } \\
\text { values }\end{array}$ & Wärnberg et al. 2006 \\
\hline
\end{tabular}

Table 2. Inflammation-related biomarkers known to be altered in obesity

In the early 2000s, studies in mice showed that the adipose tissue of obese animals was more densely macrophage-infiltrated than that belonging to lean mice. Those macrophages appeared as crown-shaped aggregates, larger with increasing degrees of obesity, and similar to those observed in known inflammatory situations, like rheumatoid arthritis. This finding led to the idea that immune function could be impaired in obesity, and the formation of 
macrophage aggregates could partially explain the related inflammatory state (Weisberg et al. 2003). Later, two different adipose tissue macrophage phenotypes have been described: the M1 or "classically activated", which acts as pro-inflammatory, and the M2 or "alternatively activated", which acts as anti-inflammatory. Obesity is associated with a phenotypic switch from M2 to M1 polarization (Lumeng et al. 2007). Furthermore, specific deletion of M1 macrophages may improve insulin sensitivity and reduce inflammatory markers (Patsouris et al., 2008, as cited in Nicholls et al., 2011), while absence of the M2 phenotype has been associated with higher susceptibility to obesity, inflammation, and insulin resistance (Odegaard et al., 2007, as cited in Nicholls et al., 2011).

\subsection{Obesity, adipokines and cytokines}

Adipose tissue secretes a great number of bioactive molecules of different nature, collectively termed adipokines, many of which have immunomodulatory actions. This is the case for the two paradigmatic adipokines, leptin and adiponectin. Leptin, the first adipokine to be discovered, is known to regulate immune function on various levels: it can stimulate monocyte proliferation and differentiation into macrophages, modulate activation of natural killer lymphocytes, and induce the production of pro-inflammatory cytokines, such as TNFa, IL-6, or IL-12 (Tilg \& Moschen, 2006). Adiponectin, considered as an anti-inflammatory and insulin-sensitizing hormone, exerts opposite actions. It inhibits the phagocytic activity and production of TNF- $\alpha$ in macrophages, the differentiation of monocyte precursors, the synthesis of endothelial adhesion molecules, and the formation of foam cells (Koerner et al., 2005), and stimulates the release of anti-inflammatory interleukins, like IL-10 or IL-1ra (Tilg \& Moschen, 2006). In obesity, circulating leptin levels are increased, in parallel with body fat mass; on the contrary, adiponectin concentrations correlate inversely with body weight. These changes may contribute to the onset and maintenance of the systemic inflammation present in obesity.

Obese subjects also show elevated circulating levels of various inflammation-related molecules, like C-reactive protein (CRP), haptoglobin, TNF-a, IL-6, or components of the complement system, and this event is linked to the concomitant development of insulin resistance, metabolic disorders, or the increased cardiovascular risk seen in obesity (Wärnberg et al. 2006; Hotamisligil 2006). The raise of inflammatory markers has its roots in the enlargement of body fat mass, and it is explained largely, but not completely, by the infiltrated macrophage-dependent production of cytokines and chemokines. Adipocytes and macrophages share certain phenotypic features, including the capacity to produce and release cytokines. Fat cells secrete, amongst others, TNF- $\alpha$, IL-6, monocyte chemotactic protein (MCP)-1, TGF- $\beta$, or acute phase proteins (revised in Trayhurn \& Wood, 2004). Consequently, dysfunction of adipose tissue plays a key role in the development of the obesity-associated systemic inflammation and related pathologies.

Lifestyle-aimed interventions seem to be useful to improve the inflammatory condition in obese subjects. Environmental factors such as physical activity may counteract the consequences of excessive body fat. Cardiorespiratory fitness has been inversely associated with serum levels of inflammatory markers such as CRP and complement factors C 3 and C4, all of which were positively associated with body fat (Martínez-Gómez et al., 2010). An intervention programme carried out on overweight/obese adolescents (aged 13-16 years) to promote a healthy lifestyle and lose weight (the EVASYON study), resulted in decreased 
serum levels of leptin and several cytokines (IL-8, IL-10 and TNF-a), without affecting those of adiponectin, total peptide $Y Y$, or even insulin, and these changes seemed to depend on physical activity and fitness (Romeo et al., 2011).

\subsection{Proposed mechanisms linking obesity and inflammation in adipose tissue 3.3.1 Fatty acid-induced inflammation}

Abnormally elevated blood lipid levels, including free fatty acids, are a common feature in obesity. There are different explanations for this increase. One is known as the "adipose tissue expandability" hypothesis (Virtue \& Vidal-Puig, 2010, as cited in Pietiläinen et al., 2011). According to this hypothesis, the adipose tissue has a limited capacity to expand and to store energy. When this limit is exceeded, it leads to enhanced lipolysis within the adipocyte and the subsequent release of free fatty acids into the bloodstream, reaching other tissues and organs, in which they exert toxic effects -a phenomenon known as lipotoxicity. Other studies have demonstrated that inflammatory cytokines increase free fatty acid levels (Grunfeld \& Feingold, 1991, as cited in Mei et al., 2011). Finally, recent observations suggest that chronic systemic inflammation stimulates lipolysis and decreases lipogenesis in adipose tissue, while increasing lipid synthesis in skeletal muscle and liver (Mei et al., 2011).

The chemical nature of fatty acids is also relevant in triggering the inflammatory response. Studies with weight-discordant twins have shown that obese individuals, who exhibited signs of insulin resistance and elevated inflammatory and immune response pathways in the adipose tissue when compared to their lean twins, also showed significant differences in adipose tissue fatty acid composition (Pietiläinen et al., 2011). There seems to be a positive feedback loop involving saturated fatty acids (SFA) from adipocytes and cytokines from macrophages, which accelerates the inflammatory change in the adipose tissue in obesity. SFA can increase the production of TNF-a in macrophages, and in turn the latter induce lipolysis in adipocytes (Suganami et al., 2007).

Fatty acids have been suggested to modulate adipokine production and/or secretion. Likewise in macrophages, SFA may stimulate TNF- $\alpha$ and IL-6 expression and release in adipocytes (reviewed in Stryjecki \& Mutch, 2011). Adiponectin levels also seem to be associated with fatty acids, being this correlation negative with SFA, palmitoleic (16:1n7) or $\gamma$-linolenic (18:3n6) fatty acids, and positive with oleic acid, or total n-6 and n-3 polyunsaturated fatty acids (PUFA) (Fernandez-Real et al., 2005; Pérez de Heredia et al., 2009).

Alternatively, fatty acids may directly elicit the inflammatory response, through activation of cell receptors. For instance, they are natural ligands for peroxisome proliferator-activated receptors (PPARs); these transcription factors, apart from regulating cell metabolism and adipocyte formation, can suppress the activity of the nuclear factor kappa B (NF-kB), a crucial transcription factor in the initiation of the inflammatory response, and they seem to be involved in the aforementioned phenotypic switch of adipose tissue-resident macrophages (reviewed in Coll et al., 2010). On the other hand, recent evidence has suggested that fatty acids, especially SFA, could also act through the toll-like receptors (TLRs), the activation of which induces the synthesis of inflammatory markers in macrophages and aggravates insulin resistance (Fessler et al., 2009, as cited in Stryjecki \& Mutch 2011). 


\subsubsection{Endoplasmic reticulum stress}

The excessive adipose tissue growth has further consequences at the cellular and subcellular levels, and a role has been suggested for endoplasmic reticulum stress in the origin of adipocyte dysfunction in obesity. The endoplasmic reticulum (ER) is a primary site for protein synthesis and triglyceride droplet formation. Under conditions of cellular stress, ER function becomes progressively impaired and this triggers a security mechanism known as the "unfolded protein response" (UPR). The increased demand for protein and triglyceride droplet formation under nutrient excess and cell expansion in obesity may as well induce ER stress and the UPR. Additionally, nutrients themselves may serve as signals leading to ER stress; in relation to the previous section, free fatty acids have been shown to induce the UPR in various cell types. The UPR is linked to the production of reactive oxygen species (ROS) and the activation of inflammatory pathways, with increased expression of cytokines, including IL-8, IL-6, MCP-1, and TNF-a. Paradoxically, glucose deprivation could contribute to ER stress in obesity; this could happen as a result of insulin resistance developing within the adipose tissue. Finally, closing a positive feed-back loop, the inflammatory condition in the obese adipose tissue induces the UPR and enhances ER stress (reviewed in Gregor \& Hotamisligil, 2007).

\subsubsection{Hypoxia in adipose tissue}

The capacity of adipose tissue to change size surpasses that of other organs and tissues. Therefore, adipose tissue expansion in obesity eventually reaches a point where the development of local vasculature is insufficient and cannot meet the oxygen and nutrient demands of distant and enlarged adipocytes. It was hypothesized that hypoxic adipocytes would then produce inflammatory signals in order to stimulate angiogenesis, and later studies in animal and culture models have confirmed this hypothesis (reviewed in Trayhurn et al., 2010). The key element in the initiation of the cellular response to hypoxia is the hypoxia-inducible factor 1 (HIF-1), a transcription factor highly unstable under normal normoxic conditions, but which becomes stabilized when oxygen availability is low. Once stabilized, HIF-1 regulates the expression of a great number of genes involved in different functions that include angiogenesis, inflammation and energy metabolism; some of these genes are leptin, PAI-1 (plasminogen activator inhibitor 1), or MIF (macrophage migration inhibitory factor), which become up-regulated, or adiponectin, which becomes downregulated (Trayhurn et al., 2010). Hypoxia has in addition important consequences for adipocyte metabolism, as it forces the adipocyte to switch to anaerobic glycolysis to obtain energy from glucose. This results in increased production and release of lactate from adipocytes (Pérez de Heredia et al., 2010a). Lactate has been shown to stimulate inflammatory pathways in macrophages (Samuvel et al. 2009, as cited in Pérez de Heredia et al., 2010a) and seems to enhance lipopolysaccharide (LPS)-induced inflammatory response in preadipocytes (Pérez de Heredia et al., 2010b, as cited in Pérez de Heredia et al., 2010a).

Other cell types present in adipose tissue are responsive to hypoxia, too. Resident macrophages accumulate around hypoxic areas, probably recruited by chemotactic signals released from adipocytes, and respond to hypoxia in a similar manner to adipocytes, by producing pro-inflammatory cytokines. Preadipocytes are also sensitive to the lack of oxygen, although their response is milder than that of mature adipocytes (Trayhurn et al., 2010). 
It is apparent that the hypoxia response and HIF-1 activation fail to achieve the expected effect of increasing adipose tissue vascularization, but lead instead to a situation of local fibrosis which initiates adipose tissue dysfunction (Halberg et al., 2009, as cited in Trayhurn et al., 2010). In line with this, hypoxia has been found to induce the UPR in cultured adipocytes (Gregor \& Hotamisligil, 2007).

\subsection{The influence of the adipose depot in obesity-related inflammation}

Most characteristics of adipose tissue vary according to its anatomical localization, and these differences make the visceral depots more clinically relevant than the subcutaneous depot, in relation to the development of metabolic disturbances, insulin resistance or cardiovascular risk. With regards to inflammation, there are several features that render visceral fat more detrimental than subcutaneous one. Firstly, adiponectin gene expression has been found to be lower in visceral than in subcutaneous adipose tissue (HernándezMorante et al., 2006). Secondly, infiltration of macrophages seems to be greater in visceral than in subcutaneous adipose tissue in obesity (Cancello et al., 2006, as cited in Villaret et al., 2010). And more recently, it has been observed that, in obese subjects, endothelial cells isolated from visceral (omental) fat show a higher expression of genes related to angiogenesis and inflammation than endothelial cells from subcutaneous adipose tissue (Villaret et al., 2010). In addition, the expression of hypoxia-related genes seems to be greater in the visceral adipose tissue, even when it could not be attributed to poorer vascularization in this depot, as compared to the subcutaneous one. Moreover, the cells from visceral fat show more evident signs of cellular senescence than those from subcutaneous fat (Villaret et al., 2010).

In conclusion, obesity-associated chronic systemic inflammation has its origin in adipose tissue dysfunction, and various plausible explanations have been proposed for the phenomenon, although more research is needed to confirm the precise mechanisms for adipose tissue inflammatory response.

\section{Celiac disease}

Celiac disease (CD) is defined as a permanent intolerance to gluten proteins of wheat, barley and rye. The only treatment for this chronic disease is a lifelong and strict glutenfree diet (GFD) (Mujico et al., 2011). Although CD has been considered a primary gastrointestinal disease, this disease can affect other systemic organs, including the skin, blood (hematologic system) and bone. Recent evidence indicates that both innate and adaptive immune responses are necessary for the phenotypic expression and pathologic changes characteristic of CD (De Nitto et al., 2009). In genetically predisposed individuals, the adaptive response, mediated by the activation of antigen-specific $\mathrm{T}$ lymphocytes, drives a pro-inflammatory response, which ends in an immune-mediated enteropathy characterized by villous atrophy, crypt hyperplasia, recruitment of intraepithelial lymphocytes (IELs), and increase of numerous inflammation-related biomarkers (Table 3). In addition, some gluten peptides are able to induce an innate immune response in intestinal mucosa. There is evidence of a direct toxic effect of some gluten peptides in several biological models. However, the failure to control the inflammatory response may be one of the factors underlying gluten intolerance in these individuals (Garrote et al., 2008). 


\begin{tabular}{|c|c|c|}
\hline Biomarker & Source & Reference \\
\hline IFN- $\alpha$ & Intestinal mucosa cultures & $\begin{array}{l}\text { Monteleone et al., 2001, as cited in De Nitto et } \\
\text { al., } 2009\end{array}$ \\
\hline \multirow{3}{*}{ IFN-Y } & Intestinal mucosa cultures & $\begin{array}{l}\text { Nielsen et al., } 1995 \text { \& 1998; as cited in De Nitto } \\
\text { et al., } 2009\end{array}$ \\
\hline & $\mathrm{CD}^{+}$a $\beta$ IELs & Forsberg et al., 2007 \\
\hline & Seruma & Manavalan et al., 2010 \\
\hline IL-1a & Serum $^{b}$ & Manavalan et al., 2010 \\
\hline IL-1 $\beta$ & Serum $^{b}$ & Manavalan et al., 2010 \\
\hline IL-2 & Seruma & Manavalan et al., 2010 \\
\hline IL-4 & Seruma,b,c & Manavalan et al., 2010 \\
\hline IL-6 & Serum ${ }^{\mathrm{c}, \mathrm{d}}$ & $\begin{array}{l}\text { Manavalan et al., } 2010 \\
\text { Fornari et al., 1998; Romaldini et al., 2002; as } \\
\text { cited in Manavalan et al., } 2010\end{array}$ \\
\hline IL-8 & Serum ${ }^{\mathrm{b}, \mathrm{c}, \mathrm{e}}$ & Manavalan et al., 2010 \\
\hline \multirow[b]{2}{*}{ IL-10 } & $\mathrm{CD}^{+}{ }^{+}$and $\mathrm{CD} 8^{+} \alpha \beta$ IELs & Forsberg et al., 2007 \\
\hline & Serum ${ }^{a, b}$ & $\begin{array}{l}\text { Manavalan et al., } 2010 \\
\text { Cataldo et al., 2003, as cited in Manavalan et } \\
\text { al., } 2010\end{array}$ \\
\hline \multirow{2}{*}{ IL-15 } & $\begin{array}{l}\text { Lamina propria and } \\
\text { intestinal epithelium }\end{array}$ & $\begin{array}{l}\text { Di Sabatino et al., } 2006 \\
\text { Maiuri et al., 2000; Mention et al., 2003; as cited } \\
\text { in De Nitto et al., } 2009\end{array}$ \\
\hline & $\begin{array}{l}\text { Lamina propria } \\
\text { macrophages and dendritic } \\
\text { cells }\end{array}$ & $\begin{array}{l}\text { Maiuri et al., 2003, as cited in De Nitto et al., } \\
2009\end{array}$ \\
\hline IL-15Ra & IELs & Di Sabatino et al., 2006 \\
\hline IL-18 & $\begin{array}{l}\text { Crypts of intestinal mucosa } \\
\text { cultures }\end{array}$ & León et al., 2006 \\
\hline IL-21 & Intestinal mucosa cultures & Fina et al., 2008, as cited in De Nitto et al., 2009 \\
\hline \multirow{2}{*}{ TNF- $a$} & $\mathrm{CD}^{+}{ }^{+} \mathrm{a} \beta \mathrm{IELS}$ & Forsberg et al., 2007 \\
\hline & Serum & Manavalan et al., 2010 \\
\hline \multirow{3}{*}{ Zonulin } & Intestinal tissue lysates & Fasano et al., 2000, as cited in Visser et al., 2009 \\
\hline & Intestinal cell lines & $\begin{array}{l}\text { Clemente et al., 2003; Drago et al., 2006; as } \\
\text { cited in Visser et al., } 2009\end{array}$ \\
\hline & Serum ${ }^{\mathrm{d}}$ & Fasano et al., 2000, as cited in Visser et al., 2009 \\
\hline
\end{tabular}

a Patients on GFD for less than 1 year had significantly higher levels of these biomarkers compared with the patients on GFD for more than 1 year.

b Levels of these biomarkers correlated with the TTG IgA levels.

c Levels of these biomarkers correlated with the degree of mucosal damage.

d Levels of these biomarkers decreased following a GFD.

e Levels of these biomarkers remained elevated despite a GFD and remained so even after a year of gluten exclusion.

Table 3. Increased inflammation-related biomarkers in celiac disease 


\subsection{Link between gliadin, zonulin, and increased intestinal permeability in CD}

The intestinal epithelium is the largest mucosal surface and provides an interface between the external environment and the mammalian host. Healthy and mature gut mucosa with its intact tight junctions (TJ) serves as the main barrier to the passage of macromolecules (Visser et al., 2009). In a physiological state, quantitatively small but immunologically active antigens may cross the mucosal barrier. When the integrity of the gut barrier is compromised (TJ disassembly), an immune response to environmental antigens that crossed the gut mucosa may be developed, leading to autoimmune diseases or food allergies (Fasano, 2001b; Mowat, 2003; as cited in Visser et al., 2009).

Several autoimmune diseases are characterized by loss of intestinal barrier function (Fasano, 2001a, as cited in Visser et al., 2009). Quantitative immunoblotting of intestinal tissue lysates from active $C D$ ( $A C D$ ) patients confirmed the increase in zonulin protein (a human intestinal homolog of zonula occludens toxin, an enterotoxin that reversibly opens the TJ) compared to control tissues. The zonulin upregulation during the acute phase of CD was confirmed by measuring zonulin concentration in sera of 189 CD patients using a sandwich enzyme-linked immunosorbent assay (ELISA). Compared to healthy controls, CD subjects showed significantly higher zonulin serum concentrations during the acute phase of the disease that decreased following a GFD (Fasano et al., 2000, as cited in Visser et al., 2009).

Intestinal cell lines exposed to gliadin released zonulin in the cell medium with subsequent zonulin binding to the cell surface, rearrangement of the cell cytoskeleton, loss of occludinZO1 protein-protein interaction, and increased monolayer permeability. Pre-treatment with the zonulin antagonist AT1001 blocked these changes without affecting zonulin release. When exposed to luminal gliadin, intestinal biopsies from celiac patients in remission expressed a sustained luminal zonulin release and increase in intestinal permeability. Conversely, biopsies from non-CD patients demonstrated a limited, transient zonulin release, which was paralleled by a reduction in intestinal permeability that never reached the level of permeability seen in CD tissues. Interestingly, when gliadin was added to the basolateral side of either cell lines or intestinal biopsies, no zonulin release was detected (Clemente et al., 2003; Drago et al., 2006; as cited in Visser et al., 2009). It has been postulated that gliadin binds to the chemokine receptor CXCR3, expressed in human and mouse intestinal epithelium and lamina propria, and leads to activation of the zonulin pathway and increased intestinal permeability in a MyD88-dependent fashion (Lammers et al., 2008, as cited in Visser et al., 2009).

\subsection{The mucosal cytokine network involved in CD}

Although the pathogenesis of CD is not fully understood, it is known that gluten peptides are deamidated by tissue transglutaminase and presented by $\mathrm{DQ}^{+}$or $\mathrm{DQ}^{+}$antigenpresenting cells to lamina propria CD4 ${ }^{+} \mathrm{T}$ cells (Di Sabatino \& Corazza, 2009; Sjöström et al., 1998; as cited in De Nitto et al., 2009). Upon activation, CD4 ${ }^{+} \mathrm{T}$ cells polarize along the $\mathrm{T}$ helper (Th)1-type pathway, as substantiated by their ability to produce large amounts of IFN- $\gamma$, the signature cytokine of Th1 responses. In CD patients on a GFD, IFN- $\gamma$ production is as low as in healthy controls but it can be stimulated in vitro by gluten to reach levels of ACD patients. In these mucosal cultures, neutralization of IFN- $\gamma$ prevents gliadin-mediated morphological changes thus supporting the role of the adaptive immune response and IFN$\gamma$ in CD immunopathology (Nielsen et al., 1995 \& 1998; as cited in De Nitto et al., 2009).

ACD is also characterized by a prominent cytokine response of IELs to gluten-containing diet. CD8 ${ }^{+}$a $\beta$ IELs retrieved from small intestinal biopsies of children with ACD showed a 
significant increase in expression levels of both IFN- $\gamma$ and IL-10, the latter also increased in $\mathrm{CD}^{+}$aßIELs. Production of IL-10 may be a common feature of IELs producing proinflammatory cytokines, attempting to limit inflammation in an autocrine fashion (Forsberg et al., 2007). TNF-a levels were increased in CD4+ aßIELs, which also showed the highest expression level per cell and constituted the major source of this cytokine. Cytokine levels were low in үठIELs (Forsberg et al., 2007).

Some gluten peptides can induce mucosal damage by directly activating innate immune mechanisms. In particular, it was shown that the p31-43 peptide elicits the production of IL15 by lamina propria macrophages and dendritic cells in ex vivo organ cultures of $\mathrm{CD}$ biopsies, thus triggering a sequence of events that culminates in epithelial damage (Maiuri et al., 2003, as cited in De Nitto et al., 2009). These findings correlate well with the demonstration that IL-15 is over-expressed in both the lamina propria and intestinal epithelium of patients with ACD as compared with normal controls or GFD treated CD patients (Maiuri et al., 2000; Mention et al., 2003; as cited in De Nitto et al., 2009). The levels of IL-15 also correlate with the degree of mucosal damage (Di Sabatino et al., 2006).

Epithelium derived IL-15, signalling via IL-15Ra, is critical for the development, activation, and survival of IELs. The IELs of ACD, characterised by higher IL-15Ra expression, showed increased proliferation, production of IFN- $\gamma$ and TNF- $\alpha$, and perforin/granzyme dependent cytotoxicity, and a decreased propensity to apoptosis in response to IL-15 (Di Sabatino et al., 2006). These findings suggest that IL-15 plays a crucial role in the generation of epithelial damage in active CD. Blocking IL-15, by suppressing uncontrolled IEL activation and survival, has the potential to provide new therapeutic tools to prevent tissue damage and lymphomagenesis in CD (Di Sabatino et al., 2006).

Biopsies taken from CD patients on a GFD over-expressed IL-21 when challenged in vitro with gluten peptides. Interestingly, neutralization of IL-21 activity in ex vivo organ cultures of CD biopsies reduced IFN-ץ production (Fina et al., 2008, as cited in De Nitto et al., 2009). IFN-a, which is up-regulated in the mucosa of active CD patients and contributes to intensifying IFN- $\gamma$ production, enhanced the mRNA expression of IL-21 in activated human T cells, thus suggesting a role for IFN-a in the positive control of IL-21 in CD (Monteleone et al., 2001; Strengell et al., 2004; as cited in De Nitto et al., 2009). It is tempting to speculate that IL-21 is part of a positive feedback loop that helps amplify and stabilize the committed Th1 cell phenotype in CD (De Nitto et al., 2009).

Both the active and inactive forms of IL-18 protein have been found in all samples from ACD, and protein expression was only localized within the crypts (León et al., 2006). In $\mathrm{ACD}$, the early response following gluten intake characterized by high IFN- $\gamma$ levels is driven by IL-18, and probably IL-15, and this alternates with periods of long-standing inflammation with moderate IFN-ү levels, maintained by IL-18 alone (León et al., 2006).

All these observations collectively underline the complexity of the pathogenic mechanism in $\mathrm{CD}$ and suggest that the $\mathrm{CD}$-associated mucosal damage relies on the activation of multiple rather than single cell pathways (De Nitto et al., 2009).

\subsection{Serum cytokine levels in CD}

Since the identification of tissue transglutaminase (TTG) as the autoantigen of CD, detection of anti-TTG IgA antibodies in the serum of CD patients has become an essential tool for the diagnosis of this disorder. Patients with ACD and those on a GFD with positive TTG IgA antibodies had significantly higher serum levels of pro-inflammatory cytokines, such as IFN- $\gamma$, IL-1 $\beta$, TNF- $\alpha$, IL-6 and IL-8, and also Th2 cytokines such as IL-4 and IL-10, compared 
with normal controls and patients on GFD without antibodies (Manavalan et al., 2010). There are also data documenting elevated serum levels of IL-10 in CD patients with underlying IgA deficiency (Cataldo et al., 2003, as cited in Manavalan et al., 2010) and high serum levels of IFN- $\gamma$ in other autoimmune diseases, some of which are associated with CD (Stepniak \& Koning, 2006, as cited in Manavalan et al., 2010).

Patients on GFD for less than 1 year had significantly higher levels of both proinflammatory cytokines (IL-2 and IFN- $\gamma$ ) and Th2 cytokines (IL-4 and IL-10) compared with the patients on GFD for more than 1 year (Manavalan et al., 2010). In other studies, serum IL-6 levels have been also found to be significantly increased in patients with ACD compared with controls, and decreased after following GFD for one year (Fornari et al., 1998; Romaldini et al., 2002; as cited in Manavalan et al., 2010). Only serum IL-8 levels remained elevated despite a GFD and remained so even after a year of gluten exclusion (Manavalan et al., 2010). It was in contrast to what has been described in patients with dermatitis herpertiformis, in whom serum IL-8 levels returned to normal levels within 2 years on a GFD (Hall et al., 2007, as cited in Manavalan et al., 2010).

In addition, a statistically significant correlation between levels of TTG IgA titers and serum levels of Th2 cytokines IL-4, IL-10 and inflammatory cytokines such as IL-1 $\alpha$, IL-1 $\beta$, and IL-8 was observed. Moreover, using linear regression analysis, serum levels of IL-4, IL-6 and IL-8 were found to correlate with the degree of villous atrophy (Manavalan et al., 2010). Higher levels of serum cytokines in patients with severe degrees of villous atrophy suggest a link between local mucosal alterations and systemic immune activation in this disease.

These results suggest that patients with CD have high levels of circulating pro- and antiinflammatory cytokines, especially during the active phase of the disease, and differ from those of otherwise healthy individuals. Interestingly, most of these cytokines decrease when the patients commence a GFD; however a few cytokines that have been involved in the pathogenesis of tissue damage in $\mathrm{CD}$, such as IFN- $\gamma$, persist in the circulation despite GFD. Therefore, the serum cytokine profile does not seem to mirror the cytokine profile of the inflamed small intestinal mucosa of ACD patients. Cytokine elevations have also been reported in other diseases or disorders frequently associated with CD, including autoimmune thyroiditis, diabetes, hepatitis, osteopenia, as well as psychiatric manifestations, especially depression. It is likely that elevated levels of certain serum cytokines might underlie extraintestinal manifestations of CD (Manavalan et al., 2010).

\section{Conclusion}

In this chapter we have discussed three paradigmatic cases of malnutrition that have a strong immune and inflammatory impact: anorexia nervosa (AN) and bulimia nervosa (BN), obesity, and celiac disease (CD). These patients have dysregulated levels of various inflammation-related molecules, especially during the active phase of the disease, and differ from those of otherwise healthy individuals. It is likely that these alterations might contribute to the onset and maintenance of the systemic inflammation. The failure to control the inflammatory response may be one of the factors underlying forthcoming complications and concomitant development of other diseases or disorders, including autoimmune thyroiditis, diabetes, hepatitis, osteopenia, psychiatric manifestations (especially depression), as well as some types of cancer. Consequently, malnutrition plays a key role in the development of associated systemic inflammation and related pathologies. All these observations collectively underline the complexity of the pathogenic mechanisms of these 
diseases and suggest that the damage relies on the activation of multiple rather than single cell pathways.

\section{References}

Allende, L.M.; Corell, A.; Manzanares, J.; Madruga, D.; Marcos, A; Madroño, A.; LópezGoyanes, A.; García-Pérez, M.A.; Moreno, J.M.; Rodrigo, M.; Sanz, F. \& ArnaizVillena, A. (1998). Immunodeficiency associated with anorexia nervosa is secondary and improves after refeeding. Immunology, Vol.94, No.4, (August 1998), pp. 543-551, ISSN 0019-2805

Arita, Y.; Kihara, S.; Ouchi, N.; Takahashi, M.; Maeda, K.; Miyagawa, J.; Hotta, K.; Shimomura, I.; Nakamura, T.; Miyaoka, K.; Kuriyama, H.; Nishida, M.; Yamashita, S.; Okubo, K.; Matsubara, K.; Muraguchi, M.; Ohmoto, Y.; Funahashi, T.; Matsuzawa, Y. (1999). Paradoxical decrease of an adipose-specific protein, adiponectin, in obesity. Biochemical and Biophysical Research Communications, Vol.257, No.1, (April 1999), pp. 79-83, ISSN 0006-291X

Bessler, H.; Karp, L.; Notti, I.; Apter, A.; Tyano, S.; Djaldetti, M. \& Weizman, R. Cytokine production in anorexia nervosa. Clinical neuropharmacology, Vol.16, No.3, (June 1993), pp. 237-243, ISSN 0362-5664

Bulló, M.; García-Lorda, P.; Megias, I. \& Salas-Salvadó, J. (2003). Systemic inflammation, adipose tissue tumor necrosis factor, and leptin expression. Obesity Research, Vol.11, No.4, (April 2003), pp. 525-31, ISSN 1930-7381

Cancello, R.; Tordjman, J.; Poitou, C.; Guilhem, G.; Bouillot, J.L.; Hugol, D.; Coussieu, C.; Basdevant, A.; Bar Hen, A.; Bedossa, P.; Guerre-Millo, M. \& Clement, K. (2006). Increased infiltration of macrophages in omental adipose tissue is associated with marked hepatic lesions in morbid human obesity. Diabetes, Vol.55, No.6, (June 2006), pp. 1554-1561, ISSN 0012-1797

Caspar-Bauguil, S.; Cousin, B.; Galinier, A.; Segafredo, C.; Nibbelink, M.; André, M.; Casteilla, L. \& Pénicaud, L. (2005). Adipose tissues as an ancestral immune organ: Site-specific change in obesity. FEBS Letters, Vol.579, No.17, (July 2005), pp. 34873492, ISSN 0014-5793

Cleary, B.S.; Gaudiani, J.L. \& Mehler, P.S. (2010). Interpreting the complete blood count in anorexia nervosa. Eating disorders, Vol.18, No.2, (March 2010), pp. 132-139, ISSN 1064-0266

Coll, T.; Barroso, E.; Alvarez-Guardia, D.; Serrano, L.; Salvadó, L.; Merlos, M.; Palomer, X. \& Vázquez-Carrera, M. (2010). The role of peroxisome proliferator-activated receptor beta/delta on the inflammatory basis of metabolic disease. PPAR Research, (July 2010), pii: 368467, eISSN 1687-4765

De Nitto, D; Monteleone, I.; Franzè, E.; Pallone, F. \& Monteleone, G. (2009). Involvement of interleukin-15 and interleukin-21, two gamma-chain-related cytokines, in celiac disease. World Journal of Gastroenterology, Vol.15, No.37, (October 2009), pp. 46094614, ISSN 1007-9327

Di Sabatino, A.; Ciccocioppo, R.; Cupelli, F.; Cinque, B.; Millimaggi, D.; Clarkson, M.M.; Paulli, M.; Cifone, M.G. \& Corazza, G.R. (2006). Epithelium derived interleukin 15 regulates intraepithelial lymphocyte Th1 cytokine production, cytotoxicity, and survival in coeliac disease. Gut, Vol.55, No.4, (August 2005), pp. 469-477, ISSN 0017-5749 
Fernández-Real, J.M.; Vendrell, J. \& Ricart W. (2005). Circulating adiponectin and plasma fatty acid profile. Clinical Chemistry, Vol.51, No.3, (March 2005), pp. 603-609, ISSN 0009-9147

Fessler, M.B.; Rudel, L.L. \& Brown J.M. (2009). Toll-like receptor signaling links dietary fatty acids to the metabolic syndrome. Current Opinion in Lipidology, Vol.20, No.5, (October 2009), pp. 379-385, ISSN 0957-9672

Gregor, M.F. \& Hotamisligil, G.S. (2007). Thematic review series: Adipocyte Biology. Adipocyte stress: the endoplasmic reticulum and metabolic disease. Journal of Lipid Research, Vol.48, No.9, (September 2007), pp. 1905-1914, eISSN 1539-7262

Grunfeld, C. \& Feingold, K.R. (1991). The metabolic effects of tumor necrosis factor and other cytokines. Biotherapy, Vol.3, No.2, (1991), pp. 143-158, ISSN 1573-8280

Halberg, N.; Khan, T.; Trujillo, M.E.; Wemstedt-Asterholm, I.; Attie, A.D.; Sherwani, S.; Wang, Z.V.; Landskroner-Eiger, S.; Dineen, S.; Magalang, U.J.; Brekken, R.A. \& Scherer, P.E. (2009). Hypoxia-inducible factor 1a induces fibrosis and insulin resistance in white adipose tissue. Molecular and Cellular Biology, Vol.29, No.16, (August 2009), pp. 4467-4483, eISSN 1098-5549

Flierl MA, Gaudiani JL, Sabel AL, Long CS, Stahel PF, Mehler PS. Complement C3 serum levels in anorexia nervosa: a potential biomarker for the severity of disease? Annals of general psychiatry, No.10, (May 2011), article 16, ISSN 1744-859X

Forsberg, G.; Hernell, O.; Hammarström, S. \& Hammarström, M.L. (2007). Concomitant increase of IL-10 and pro-inflammatory cytokines in intraepithelial lymphocyte subsets in celiac disease. International Immunology, Vol.19, No.8, (July 2007), pp. 9931001, ISSN 0953-8178

Garrote, J.A.; Gómez-González, E.; Bernardo, D.; Arranz, E. \& Chirdo, F. (2008). Celiac disease pathogenesis: the proinflammatory cytokine network. Journal of pediatric gastroenterology and nutrition, Vol.47, Suppl.1, (August 2008), pp. S27-32, ISSN 02772116

Hernández-Morante, J.J.; Milagro, F.; Gabaldon, J.A.; Martínez, J.A.; Zamora, S. \& Garaulet, M. (2006). Effect of DHEA-sulfate on adiponectin gene expression in adipose tissue from different fat depots in morbidly obese humans. European Journal of Endocrinology, Vol.155, No.4, (October 2006), pp. 593-600, ISSN 0804-4643

Hotamisligil, G. S. (2006). Inflammation and metabolic disorders. Nature, Vol.444, No.7121, (December 2006), pp. 860-867, ISSN 0028-0836

Koerner, A.; Kratzsch, J. \& Kiess, W. (2005). Adipocytokines: leptin - the classical, resistin the controversial, adiponectin - the promising, and more to come. Best Practice $\mathcal{E}$ Research Clinical Endocrinology \& Metabolism, Vol.19, No.4, (December 2005), pp. 525-546, ISSN 1521-690X

Lumeng, C.N.; Bodzin, J.L. \& Saltiel, A.R. (2007). Obesity induces a phenotypic switch in adipose tissue macrophage polarization. Journal of Clinical Investigation, Vol.117, No.1, (January 2007), pp. 175-184, ISSN 0021-9738

León, A.J.; Garrote, J.A.; Blanco-Quirós, A.; Calvo, C.; Fernández-Salazar, L.; Del Villar, A.; Barrera, A. \& Arranz, E. (2006). Interleukin 18 maintains a long-standing inflammation in coeliac disease patients. Clinical and Experimental Immunology, Vol.146, No.3, (December 2006), pp. 479-85, ISSN 0009-9104 
Leoni, M.C.; Pizzo, D. \& Marchi, A. (2010). Adipocytokines: potential biomarkers for childhood obesity and anorexia nervosa (Article in Italian). Minerva pediatrica, Vol.62, No.2, (April 2010), pp. 171-178, ISSN 0026-4946

Manavalan, J.S.; Hernández, L.; Shah, J.G.; Konikkara, J.; Naiyer, A.J.; Lee, A.R.; Ciaccio, E.; Minaya, M.T.; Green, P.H. \& Bhagat, G. (2010). Serum cytokine elevations in celiac disease: association with disease presentation. Human immunology, Vol.71, No.1, (January 2010), pp. 50-57, ISSN 0198-8859

Marcos, A. (2000). Eating disorders: a situation of malnutrition with peculiar changes in the immune system. European journal of clinical nutrition, Vol.54, Suppl.1, (March 2000), pp. S61-S64, ISSN 0954-3007

Marcos, A.; Nova, E. \& Montero, A. (2003). Changes in the immune system are conditioned by nutrition. European journal of clinical nutrition, Vol.57, Suppl.1, (September 2003), pp. S66-S69, ISSN 0954-3007

Marcos, A.; Varela, P.; Santacruz, I.; Muñoz-Vélez, A. \& Morandé, G. (1993). Nutritional status and immunocompetence in eating disorders. A comparative study. European journal of clinical nutrition, Vol.47, No.11, (November 1993), pp. 787-793, ISSN 09543007.

Martínez-Gómez, D.; Eisenmann, J.C.; Wärnberg, J.; Gómez-Martinez, S.; Veses, A.; Veiga, O.L. \& Marcos, A. (2010). Associations of physical activity, fitness and fatness with low-grade inflammation in adolescents. The AFINOS study. International journal of obesity (London), Vol.34, No.10, (October 2010), pp. 1501-1507, ISSN 0307-0565

Mayer, E.A. (2011). Gut feelings: the emerging biology of gut-brain communication. Nature reviews - Neuroscience, Vol.12, No.8, (July 2011), pp. 453-466, ISSN 1471-003X

Mei, M.; Zhao, L.; Li, Q.; Chen, Y.; Huang, A.; Varghese, Z.; Moorhead, J.F.; Zhang, S.; Powis, S.H.; Li, Q. \& Ruan, X.Z. (2011). Inflammatory stress exacerbates ectopic lipid deposition in C57BL/6J mice. Lipids in Health and Disease, Vol.10, No.1, (June 2011), pp. 110, [Epub ahead of print], ISSN 1476-511X

Mujico, J.R.; Lombardía, M.; Mena, M.C.; Méndez, E. \& Albar J.P. (2011). A highly sensitive real-time PCR system for quantification of wheat contamination in gluten-free food for celiac patients. Food Chemistry, Vol.10, No.3, (October 2011), pp. 795-801, ISSN 0308-8146

Nogueira, J.P.; Maraninchi, M.; Lorec, A.M.; Corroller, A.B.; Nicolay, A.; Gaudart, J.; Portugal, H.; Barone, R.; Vialettes, B. \& Valéro, R. (2010). Specific adipocytokines profiles in patients with hyperactive and/or binge/purge form of anorexia nervosa. European journal of clinical nutrition, Vol.64, No.8, (August 2010), pp. 840-844, ISSN 0954-3007

Nova, E.; Gómez-Martínez, S.; Morandé, G. \& Marcos, A. (2002). Cytokine production by blood mononuclear cells from in-patients with anorexia nervosa. The British journal of nutrition, Vol.88, No.2, (August 2002), pp. 183-138, ISSN 0007-1145

Nova, E. \& Marcos, A. (2006). Immunocompetence to assess nutritional status in eating disorders. Expert review of clinical immunology, Vol.2, No.3, (May 2006), pp. 433-444, ISSN 1744-666X

Odegaard, J.I.; Ricardo-Gonzalez, R.R.; Goforth, M.H.; Morel, C.R.; Subramanian, V.; Mukundan, L.; Red Eagle, A.; Vats, D.; Brombacher, F.; Ferrante, A.W. \& Chawla, A. (2007). Macrophage-specific PPARgamma controls alternative activation and 
improves insulin resistance. Nature, Vol.447, No.7148, (June 2007), pp. 1116-1120, ISSN 0028-0836

Patsouris, D.; Li, P.P.; Thapar, D.; Chapman, J.; Olefsky, J.M. \& Neels, J.G. (2008). Ablation of CD11c-positive cells normalizes insulin sensitivity in obese insulin resistant animals. Cell Metabolism, Vol.8, No.4, (October 2008), pp. 301-309, ISSN 1550-4131

Pérez de Heredia, F.; Sánchez, J.; Priego, T.; Larqué, E.; Portillo, M.P.; Palou, A.; Zamora, S. \& Garaulet, M. (2009). Adiponectin is associated with serum and adipose tissue fatty acid composition in rats. Journal of Endocrinological Investigation, Vol.32, No.8, (September 2009), pp. 659-665, ISSN 0391-4097

Pérez de Heredia, F.; Wood, I.S. \& Trayhurn, P. (2010). Hypoxia stimulates lactate release and modulates monocarboxylate transporter (MCT1, MCT2, MCT4) expression in human adipocytes. Pflügers Archive - European Journal of Physiology, Vol.459, No.3, (February 2010), pp. 509-518, ISSN 0031-6768

Pérez de Heredia, F.; Wood, I.S. \& Trayhurn P. (2010). Lactate enhances the inflammatory response in human preadipocytes in vitro. Obesity Reviews, Vol.11, Suppl.1, (2010), pp. 122, ISSN 1467-789X [Abstract]

Pietiläinen, K.H.; Róg, T.; Seppänen-Laakso, T.; Virtue, S.; Gopalacharyulu, P.; Tang, J.; Rodriguez-Cuenca, S.; Maciejewski, A.; Naukkarinen, J.; Ruskeepää, A.L.; Niemelä, P.S.; Yetukuri, L.; Tan, C.Y.; Velagapudi, V.; Castillo, S.; Nygren, H.; Hyötyläinen, T.; Rissanen, A.; Kaprio, J.; Yki-Järvinen, H.; Vattulainen, I.; Vidal-Puig, A. \& Orešič, M. (2011). Association of lipidome remodeling in the adipocyte membrane with acquired obesity in humans. Public Library of Science Biology, Vol.9, No.6, (June 2011), pp-e1000623, eISSN 1545-7885

Poglio, S.; de Toni-Costes, F.; Arnaud, E.; Laharrague, P.; Espinosa, E.; Casteilla, L.; Cousin, B. (2010). Adipose tissue as a dedicated reservoir of functional mast cell progenitors. Stem Cells, Vol.28, No.11, (November 2010), pp. 2065-2072, ISSN 1066-5099

Polack, E.; Nahmod, V.E.; Emeric-Sauval, E.; Bello, M.; Costas, M.; Finkielman, S. \& Arzt, E. (1993). Low lymphocyte interferon-gamma production and variable proliferative response in anorexia nervosa patients. Journal of clinical immunology, Vol.13, No.6, (November 1993), pp. 445-451, ISSN 0271-9142

Romeo, J.; Martinez-Gomez, D.; Diaz, L.E.; Gomez-Martinez, S.; Marti, A.; Martin-Matillas, M.; Puertollano, M.A.; Veiga, O.L.; Martinez, J.A.; Warnberg, J.; Zapatera, B.; Garagorri, J.M.; Morandé, G.; Campoy, C.; Moreno, L.A.; Marcos, A. \& EVASYON Study Group. (2011). Changes in cardiometabolic risk factors, appetite-controlling hormones and cytokines after a treatment programme in overweight adolescents: preliminary findings from the EVASYON study. Pediatric Diabetes, Vol.12, (June 2011), pp. 372-380, ISSN 1399-543X

Saely, C.H.; Geiger, K. \& Drexel, H. (2010). Brown versus white adipose tissue: a minireview. Gerontology, (December 2010), DOI 10.1159/000321319, [Epub ahead of print], ISSN 0304-324X

Samuvel, D.J.; Sundararaj, K.P.; Nareika, A.; Lopes-Virella, M.F. \& Huang, Y. (2009). Lactate boosts TLR4 signaling and NF-KB pathway-mediated gene transcription in macrophages via monocarboxylate transporters and MD-2 up-regulation. The Journal of Immunology, Vol.182, No.4, (February 2009), pp. 2476-2484, ISSN 0022-1767 
Stryjecki, C. \& Mutch, D.M. (2011). Fatty acid-gene interactions, adipokines and obesity. European Journal of Clinical Nutrition, Vol.65, No.3, (March 2011), pp. 285-297, eISSN $1476-5640$

Suganami, T.; Tanimoto-Koyama, K.; Nishida, J.; Itoh, M.; Yuan, X.; Mizuarai, S.; Kotani, H.; Yamaoka, S.; Miyake, K.; Aoe, S.; Kamei, Y. \& Ogawa, Y. (2007). Role of the toll-like receptor 4/NF-kappaB pathway in saturated fatty acid-induced inflammatory changes in the interaction between adipocytes and macrophages. Arteriosclerosis, Thrombosis and Vascular Biology, Vol.27, No.1, (January 2007), pp. 84-91, ISSN 0276-5047

Terashi, M.; Asakawa, A.; Harada, T.; Ushikai, M.; Coquerel, Q.; Sinno, M.H.; Déchelotte, P.; Inui, A. \& Fetissov, S.O. (2011). Ghrelin reactive autoantibodies in restrictive anorexia nervosa. Nutrition, Vol.27, No.4, (April 2011), pp. 407-413, ISSN 0899-9007

Tilg, H. \& Moschen, A.R. (2006). Adipocytokines: mediators linking adipose tissue, inflammation and immunity. Nature, Vol.6, No.10, (October 2006), pp. 772-783, ISSN 0028-0836

Trayhurn, P.; Pérez de Heredia, F.; Wang, B. \& Wood, I.S. (2010). Hypoxia - Role in adipocyte function and dysfunction. In: Novel insight into adipose cell functions. Clément et al. (eds); Springer-Verlag Berlin Heidelberg, pp. 45-60, ISBN 9783642135163

Vaisman, N.; Barak, Y.; Hahn, T.; Karov, Y.; Malach, L. \& Barak, V. (1996). Defective in vitro granulopoiesis in patients with anorexia nervosa. Pediatric research, Vol.40, No.1, (July 1996), pp. 108-111, ISSN 0031-3998

Vaz-Leal, F.J.; Rodríguez-Santos, L.; Melero-Ruiz, M.J.; Ramos-Fuentes, M.I. \& GarcíaHerráiz, M.A. (2010). Psychopathology and lymphocyte subsets in patients with bulimia nervosa. Nutritional neuroscience, Vol.13, No.3, (Jun 2010), pp. 109-115, ISSN 1028-415X

Villaret, A.; Galitzky, J.; Decaunes, P.; Estève, D.; Marques, M.A.; Sengenès, C.; Chiotasso, P.; Tchkonia, T.; Lafontan, M.; Kirkland, J.L. \& Bouloumié, A. (2010). Adipose tissue endothelial cells from obese human subjects: differences among depots in angiogenic, metabolic, and inflammatory gene expression and cellular senescence. Diabetes, Vol.59, No.11, (November 2010), pp. 2755-2763, ISSN 0012-1797

Virtue, S. \& Vidal-Puig, A. (2010). Adipose tissue expandability, lipotoxicity and the metabolic syndrome-An allostatic perspective. Biochimica et Biophysica Acta, Vol.1801, No.3, (March 2010), pp. 338-349, ISSN 0005-2736

Visser, J.; Rozing, J.; Sapone, A.; Lammers, K. \& Fasano, A. (2009). Tight junctions, intestinal permeability, and autoimmunity: celiac disease and type 1 diabetes paradigms. Annals of the New York Academy of Sciences, No.1165, (May 2009), pp. 195-205, ISSN 0077-8923

Wärnberg, J.; Nova, E.; Moreno, L.A.; Romeo, J.; Mesana, M.I.; Ruiz, J.R.; Ortega, F.B.; Sjöström, M.; Bueno, M.; Marcos, A. \& AVENA Study Group. (2006). Inflammatory proteins are related to total and abdominal adiposity in a healthy adolescent population: the AVENA Study. American Journal of Clinical Nutrition, Vol.84, No.3, (September 2006), pp. 505-512, ISSN 0002-9165

Weisberg, S.P.; McCann, D.; Desai, M.; Rosenbaum, M.; Leibel, R.L. \& Ferrante, A.W., Jr. (2003). Obesity is associated with macrophage accumulation in adipose tissue. Journal of Clinical Investigation, Vol.112, No.12, (December 2003), pp. 1796-1808, ISSN 0021-9738

Wellen, K.E. \& Hotamisligil, G.S. (2005). Inflammation, stress, and diabetes. Journal of Clinical Investigation, Vol.115, No.5, (May 2005), pp. 1111-1119, ISSN0021-9738 


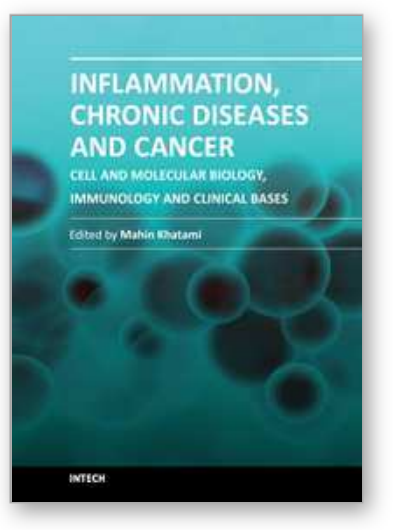

\author{
Inflammation, Chronic Diseases and Cancer - Cell and Molecular \\ Biology, Immunology and Clinical Bases \\ Edited by Dr Mahin Khatami
}

ISBN 978-953-51-0102-4

Hard cover, 430 pages

Publisher InTech

Published online 09, March, 2012

Published in print edition March, 2012

This book is a collection of excellent reviews and perspectives contributed by experts in the multidisciplinary field of basic science, clinical studies and treatment options for a wide range of acute and chronic inflammatory diseases or cancer. The goal has been to demonstrate that persistent or chronic (unresolved or subclinical) inflammation is a common denominator in the genesis, progression and manifestation of many illnesses and/or cancers, particularly during the aging process. Understanding the fundamental basis of shared and interrelated immunological features of unresolved inflammation in initiation and progression of chronic diseases or cancer are expected to hold real promises when the designs of cost-effective strategies are considered for diagnosis, prevention or treatment of a number of age-associated illnesses such as autoimmune and neurodegenerative diseases as well as many cancers.

\title{
How to reference
}

In order to correctly reference this scholarly work, feel free to copy and paste the following:

Jorge R. Mujico, Fátima Pérez-de-Heredia, Sonia Gómez-Martínez and Ascensión Marcos (2012). Malnutrition and Inflammation, Inflammation, Chronic Diseases and Cancer - Cell and Molecular Biology, Immunology and Clinical Bases, Dr Mahin Khatami (Ed.), ISBN: 978-953-51-0102-4, InTech, Available from: http://www.intechopen.com/books/inflammation-chronic-diseases-and-cancer-cell-and-molecular-biologyimmunology-and-clinical-bases/malnutrition-and-inflammation

\section{INTECH}

open science | open minds

\section{InTech Europe}

University Campus STeP Ri

Slavka Krautzeka 83/A

51000 Rijeka, Croatia

Phone: +385 (51) 770447

Fax: +385 (51) 686166

www.intechopen.com

\section{InTech China}

Unit 405, Office Block, Hotel Equatorial Shanghai

No.65, Yan An Road (West), Shanghai, 200040, China

中国上海市延安西路65号上海国际贵都大饭店办公楼 405 单元

Phone: +86-21-62489820

Fax: $+86-21-62489821$ 
(C) 2012 The Author(s). Licensee IntechOpen. This is an open access article distributed under the terms of the Creative Commons Attribution 3.0 License, which permits unrestricted use, distribution, and reproduction in any medium, provided the original work is properly cited. 